\title{
Vassilis K. Fouskas, Shampa Roy-Mukherjee, Qingan Huang and Ejike Udeogu, China \& the USA: Globalisation and the Decline of America's Supremacy
}

\author{
(E-Book: Palgrave Macmillan, 2021), 109p. \$13,96 e-Book; \$58,74 \\ Hardback
}

\section{Defne Gönenç ${ }^{1}$ (D)}

Accepted: 18 February 2021/ Published online: 8 March 2021

(C) Journal of Chinese Political Science/Association of Chinese Political Studies 2021

This is an excellent account of the political economy of China's rise vis-à-vis the U.S. and Europe. This well-organized, engaging and fluent book departs from others in the way that it contests the argument that incorporation of China into America's neoliberal globalization project worked for the benefit of the U.S. in the long run. By arguing that the Chinese state is even taking advantage of the uneven and combined development [1] generated as a result of capitalist expansion, the book differs from other critical accounts of China's global upsurge and creates a much-needed discussion about global capitalism.

The key arguments in this book are that the Western economies have been in slow and protracted decline since the 1970s (p. 73), and that Chinese political economy is set to surpass them in the near future, not only because of the importance of China in world manufacturing but because of the particular role played by the Chinese state (p. 49). Firstly, the book asserts the idea that neoliberal financial statecraft has generated unsustainable levels of debt, such that debt is no longer only a matter for the global South (p.17). Also, it notes how profits from speculative activities have soared while real economic sectors in the West have declined sharply (p.13). This situation is further exacerbated by the policy choices of Western corporate financial and political elites (p.37). In contrast, China is significantly increasing its comparative strength, through capital controls, a massive surplus of cheap labour, the use of south-east Asian platforms (p.46), a strategic focus on rare earth elements, and a shift of the nature of its exports from peripheral goods to core-strategic products (p. 49-52). Chinese policies followed after the 2007-8 financial crisis, such as welfare provision and rises in wages, in addition to China's relative success in containing the COVID-19 pandemic, have further strengthened its position vis-à-vis the West.

Defne Gönenc

defne.gonenc@yasar.edu.tr; https://cms.yasar.edu.tr/staff/ 
The book is effectively structured. The first half of the book (chapters 2-5) is devoted to the initial argument; namely, the reasons for the decline of Western economies. The second part (chapters 6-9) explains China's rise through the analysis of various data, including its management of the COVID-19 pandemic. Nevertheless, there is perhaps one omission from the work. It would have been worthwhile to have a chapter on the role of foreign direct investment and multinational companies in the Chinese rise, and about the identity of the shareholders of the multinationals functioning in China. Although there is some information about this in the book (p.50-56), it would have been better to include more detail, as the book seeks to challenge the argument that Western economies control China through multinational companies.

Content-wise, by assigning a specific role to the Chinese state in the ascendancy of its economy, the book certainly creates room for more discussion: What specifically enabled the Chinese state's particular policy choices in this development path? And, in today's world, where the state is globally taking on the role of a facilitator of capital accumulation rather than a controller, how can the Chinese state be evaluated?

Moreover, there are two absent but relevant discussions: Firstly, how have working conditions in China evolved, and to what extent is the new wealth created in China shared? How much is the working class empowered in an ascendant China? Secondly, given that global capitalism increasingly relies on mechanisation and robotics, capital might be more dependent on the environment and less dependent on labour in the near future. Correspondingly, if China continues to promote free trade policies, further environmental destruction rather than a bigger share for the middle classes at home will be the consequence. In a world where most production is undertaken by robots, trade will determine where the environmental costs of production will be incurred. In which direction will China move under such circumstances?

In sum, this is a thought-provoking work that creates room for much more discussion. In an age when some talk about a new Cold War between China and the USA (albeit an argument disputed by the book), I recommend this outstanding book, not only to those interested in China but to any keen observer of international affairs.

\section{Reference}

1. Rosenberg, Justin. 2012. The 'philosophical premises' of uneven and combined development. Review of International Studies 39 (3): 569-597.

Defne Gönenç works as a researcher at the Center for Mediterranean Studies, Yașar University. She obtained her $\mathrm{PhD}$ in International Relations and Political Science from the Graduate Institute of International and Development Studies in Geneva in 2018, and her MPhil in International Relations from Cambridge University in 2012. She works on political ecology and political economy of developing countries with a focus on the Mediterranean and India. 